\title{
Sex Differences in the Control of Social Investigation and Anxiety by Vasopressin Cells of the Paraventricular Nucleus of the Hypothalamus
}

\author{
Nicole Rigney Jack Whylings Geert J. de Vries Aras Petrulis \\ Center for Behavioral Neuroscience, Neuroscience Institute, Georgia State University, Atlanta, GA, USA
}

\section{Keywords}

Anxiety · Hypothalamus · Mice · Paraventricular nucleus of the hypothalamus - Sex differences - Social behavior .

Social communication · Vasopressin results therefore point at differential involvement of PVN AVP-expressing cells in the context of social and emotional behavior in the two sexes, which may contribute to sex differences in social communication and anxiety disorders.

(c) 2020 S. Karger AG, Basel

\section{Introduction}

The neuropeptide arginine-vasopressin (AVP; vasotocin in non-mammalian vertebrates) is an important modulator of vertebrate social behavior [1-4], including that of humans $[5,6]$. AVP acts on several receptors and in various brain regions to alter social communication [7-9], maternal care [10], pair bonding [11-13], cognition [14], and social recognition [15-17]. Studies involving blockade or stimulation of central vasopressin receptors and vasopressin knockout also implicate AVP in the generation of anxiety states and generally point at AVP acting as an anxiogenic neuromodulator [18-23]. Consequently, it is possible that AVP system effects on social behavior and communication are mediated by alterations in anxiety.

Although species differences are evident in the patterning of brain AVP receptor expression [7, 24], most brain sources of AVP exhibit a conserved anatomical dis- karger@karger.com

www.karger.com/nen

Karger"

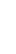

(c) 2020 S. Karger AG, Base 
tribution [17]. AVP is made in classical neurosecretory cells in the paraventricular (PVN), supraoptic, and accessory nuclei of the hypothalamus [25-30]. AVP is also made in cells that project to target areas in the brain, most notably cells in the suprachiasmatic nucleus, the bed nucleus of the stria terminalis (BNST) and medial amygdala (MA), as well as the PVN [29]. Recently, other areas, such as the accessory olfactory bulb have shown to contain AVP-expressing cells involved in social behavior [31]. The projections from the BNST and MA are sexually dimorphic, with male rodents having about twice as many AVP-expressing cells as females in these nuclei $[30,32,33]$. We have recently demonstrated that elimination of BNST AVP-expressing cells reduced specific male communicative behaviors, but that other social behaviors known to be influenced by AVP remained intact (i.e., male social investigation of female conspecifics) [34, 35]. It is plausible that other centrally projecting AVP systems, such as the PVN, are involved in regulating these aspects of social behavior. Indeed, hypothalamic and extrahypothalamic AVP inputs overlap in brain regions, such as the periaqueductal gray [36], that are involved in social behavior, communication, and emotion $[7,30,37,38]$.

AVP-expressing cells in the PVN are strong candidates for regulation of social communication as they have been implicated in both social- and stress-related behaviors and in sex-different ways. For example, high levels of AVP mRNA in the PVN coincide with increased male social interactions, but with decreased female social investigation under stress conditions $[39,40]$. However, few studies have directly tested the role of PVN AVPexpressing cells on social behavior. One study showed that PVN AVP knockdown impaired gregariousness in zebra finches [41], whereas another indicated that stimulating PVN AVP projections to the hippocampus increases social memory [42]. The effects of manipulating PVN AVP-expressing cells on social communication and behavior have not been tested in rodents.

Here, we test the hypothesis that PVN AVP is necessary for social communication and behavior in both male and female mice by deleting PVN AVP-expressing cells using a viral-mediated, cell-death construct (activated caspase) and then measuring communicative behaviors (ultrasonic vocalizations [USVs], urine marking) and social interactions (social investigation, copulatory behavior, aggression). In addition, we also measured anxietyrelated behaviors in a non-social context to clarify if any observed changes in social behavior were due to changes in anxiety.

\section{Materials and Methods}

\section{Animals and Husbandry}

All mice were maintained at $22^{\circ} \mathrm{C}$ on a $12: 12$ reverse light cycle with food and water available ad libitum and housed in individually ventilated cages (Animal Care Systems, Centennial, CO, USA) with corncob bedding, a nestlet square, and a housing tube. All animal procedures were performed in accordance with the Georgia State University animal care committee regulations and the National Institutes of Health Guide for the Care and Use of Laboratory Animals.

\section{Subjects}

AVP-IRES2-Cre-D (AVP-Cre) mice were obtained from The Jackson Laboratory (Stock No: 023530; Bar Harbor, Maine, USA). AVP-Cre knock-in mice have Cre recombinase expression directed to vasopressin-expressing cells that are restricted to populations within the hypothalamus. Subjects were derived by crossing heterozygous Cre+ mutants to wild-type C57Bl/6J mice and genotyped (ear punch) by polymerase chain reaction (PCR) at 21-24 days of age (Transnetyx, Cordova, TN, USA). Both Cre+ and Crelittermates were used in behavioral experiments. All subjects were adult mice (2-4 months old) that were singly housed for 1-2 weeks prior to testing to prevent the formation of dominant-subordinate relationships and to increase male-typical territorial behavior [43].

Stimulus Animals

CD1 (ICR; Charles River Laboratories, Wilmington, MA, USA) mice were used as stimuli for behavioral testing and to provide male and female subjects with social experience because strain differences between subjects and stimulus mice increase social investigation [44]. Mice were used at 9-16 weeks of age and were novel and unrelated to the subject to which they were exposed.

Female stimulus mice were grouped-housed, ovariectomized, and implanted with an estradiol capsule (GDX $+\mathrm{E})$, and given two sexual experiences before testing. Two groups of stimulus males were used for behavioral testing. Mice that were used as subordinate mice in the home cage aggression tests and for providing aggressive experience to subjects, were grouped-housed, gonadectomized (GDX), and subjected to two aggressive encounters with a dominant male (see below). Mice in the second group, which provided sexual experience to female subjects and served as sexual partners during copulatory tests and as stimulus animal in the three-chamber social test, were singly-housed, gonadectomized, implanted with testosterone (GDX $+\mathrm{T})$, and then given two sexual experiences before testing.

Viral Vector

AVP driven-, Cre-expressing PVN neurons were ablated using an adeno-associated virus (AAV-flex-taCasp3-TEVp; In-Stock AAV Vector - Dr. Nirao Shah; serotype 2/1; $3 \times 10^{12} \mathrm{IU} / \mathrm{mL}$; University of North Carolina at Chapel Hill Vector Core) that encodes, in a Cre-dependent fashion, a mutated pro-caspase- 3 and its activator (TEVp; Fig. 1a). This system activates an apoptotic signaling cascade, cleaving multiple structural and regulatory proteins critical for cell survival and maintenance $[45,46]$ and killing cells with far less collateral inflammation than other lesion approaches [47]. 
Fig. 1. Histology. a Cre-dependent adenoassociated virus (AAV-flex-taCasp3-TEVp) construct and location of bilateral PVN injection site; AP $-0.42 \mathrm{~mm}$; $\mathrm{ML} \pm 0.35 \mathrm{~mm}$; DV $5.2 \mathrm{~mm}$; modified from Paxinos and Franklin [48]. Representative images of fluorescent in situ hybridization-labeled PVN AVP-expressing cells (b) and OT-expressing cells (c). d Boxplots indicating individual data points, median, first, and third quartiles for PVN AVP-expressing cell number across 4 anterior-posterior sections in male and female subjects. Within the PVN, we found a significant decrease in AVP-expressing cell number in both Cre+ male and female subjects compared to Crecontrols (males: $p<0.00001$; females: $p<$ $0.00001)$. Cre $-(n=13)$ and Cre $+(n=15)$ males and Cre- $(n=11)$ and Cre+ $(n=9)$ females. e We found no significant OT-expressing cell loss between Cre+ and Cresubjects (males: $p=0.35$; females: $p=0.9$ ). Cre- $(n=3)$ and Cre+ $(n=4)$ males and Cre- $(n=4)$ and Cre+ $(n=3)$ females. Images were taken at $\times 10$, fluorescent cells per $\mathrm{mm}^{2}$, scale bar $=50 \mu \mathrm{m}$.

PVN AVP and Social Communication and Behavior in Mice
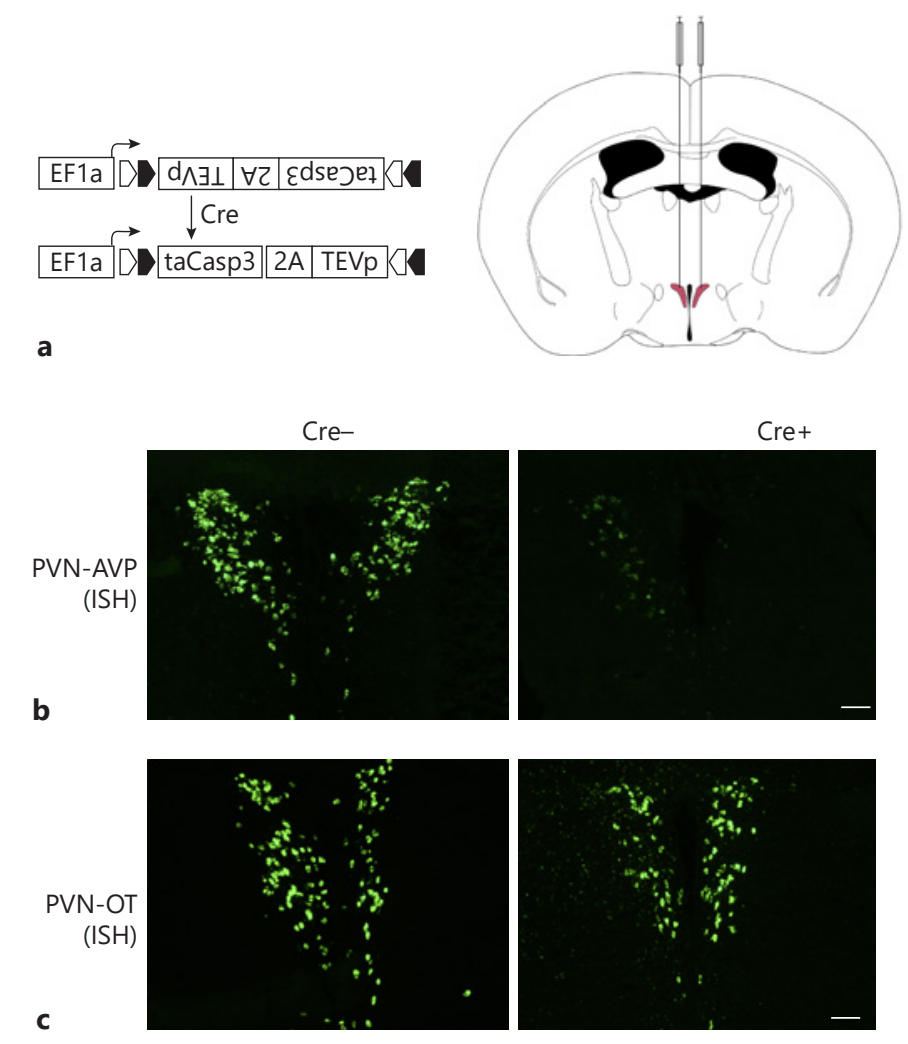

AVP
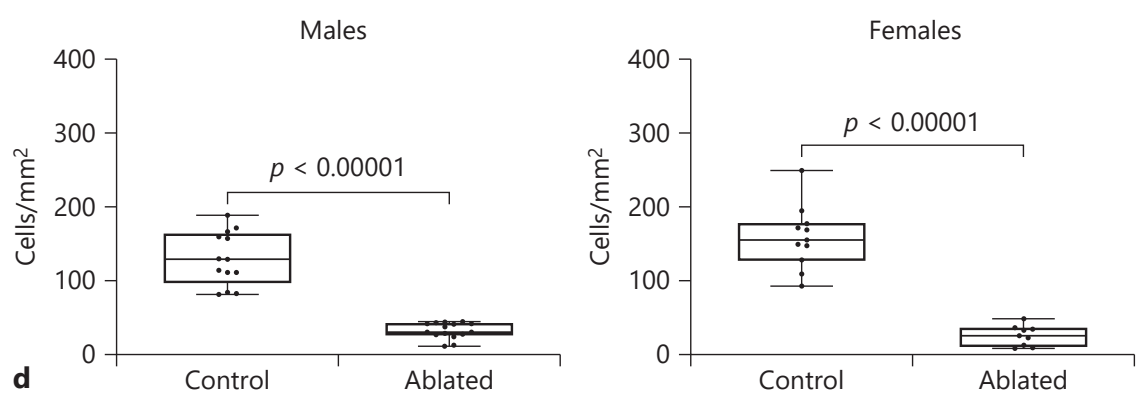

OT
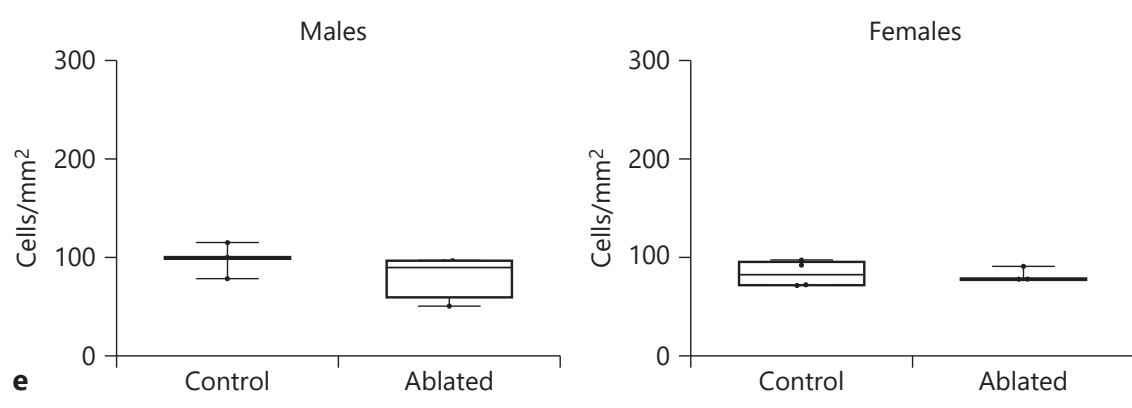


\section{Surgery}

All surgeries were carried out using 1.5-3\% isoflurane gas anesthesia in $100 \%$ oxygen; $3 \mathrm{mg} / \mathrm{kg}$ of carprofen was given subcutaneously before surgery to reduce pain.

\section{Stereotaxic Surgery}

Mice were positioned in a stereotaxic frame (David Kopf Instruments, Tujunga, CA, USA) with ear and incisor bars holding bregma and lambda level. After a midline scalp incision, a handoperated drill was used to make holes in the skull, exposing the dura. For all subjects, $700 \mathrm{~nL}$ of AAV-flex-taCasp3-TEVp was delivered bilaterally to the PVN (coordinates: AP $-0.42 \mathrm{~mm}$; $\mathrm{ML} \pm$ $0.35 \mathrm{~mm}$; DV $5.2 \mathrm{~mm}$ [48]) at a rate of $100 \mathrm{~nL} / \mathrm{min}$ using a $5-\mu \mathrm{L}$ Hamilton syringe with a 30 -gauge beveled needle mounted on a stereotaxic injector. Following virus delivery, the syringe was left in place for $15 \mathrm{~min}$ before slowly withdrawing it from the brain.

\section{Gonadectomy and Hormone Treatment}

Testes were removed after cauterizing the ductus deferens and blood supply via a midline abdominal incision. Silastic capsules (1.5-cm active length; 1.02-mm inner diameter, 2.16-mm outer diameter; Dow Corning Corporation, Midland, MI, USA) were filled with crystalline testosterone (T; Sigma, St. Louis, MO, USA) and inserted subcutaneously between the scapulae after gonadectomy; this procedure leads to physiological levels of T [49, 50]. To further reduce aggression in stimulus animals [51], some males were gonadectomized, but did not receive a $\mathrm{T}$ implant (GDX).

The ovaries of stimulus female mice were removed after cauterizing its blood supply via an abdominal incision at the uterine horn. Silastic capsules (0.7-cm active length; $1.02-\mathrm{mm}$ inner diameter, 2.16-mm outer diameter; Dow Corning Corporation, Midland, MI, USA) containing estradiol benzoate (E; diluted 1:1 with cholesterol) were implanted subcutaneously in the scapular region immediately following ovariectomy $(\mathrm{GDX}+\mathrm{E})[52,53]$. To induce sexual receptivity, stimulus females were injected subcutaneously with $0.1 \mathrm{~mL}$ of progesterone $(500 \mu \mathrm{g}$ dissolved in sesame oil; Sigma, St. Louis, MO, USA) $4 \mathrm{~h}$ preceding sexual experience, urine collection, and behavioral testing [54].

\section{Urine Collection}

Pooled urine samples were collected from stimulus females induced into estrus and from stimulus males (3-8 mice per sample). Estrous state was verified by color, swelling, and expanded size of the vaginal opening [55]. To collect urine, mice were picked up by the tail base and held by dorsal neck skin; this method typically induced urination. If the mouse did not urinate, stroking its belly from an anterior to posterior direction stimulated bladder voiding. Each mouse provided $15-50 \mu \mathrm{L}$ of urine that was pooled into a $1.5-\mathrm{mL}$ Eppendorf tube. Urine samples were used fresh within $1 \mathrm{~h}$ of collection to prevent chemosignal degradation [56].

\section{Social Experience}

As opposite-sex sexual experience and attaining competitive status ("social dominance") promote communicative behaviors $[56,57]$, mice received social experience over 5 consecutive days (sexual encounters on days 1 and 4, aggressive encounters on days 2 and 5 ; no encounters on day 3 ).
Sexual Experience

Subjects were given two opportunities to interact with either a stimulus female (for male subjects) or a stimulus male (for female subjects). A sexually experienced stimulus mouse was placed in the subject's home cage and removed the next day (first experience) or after $90 \mathrm{~min}$ (second experience). Subjects that did not ejaculate or elicit ejaculation (females) during the second sexual experience were removed from further testing.

\section{Aggressive Experience}

Male subjects were exposed to two interactions with subordinate males treated with $50 \mu \mathrm{L}$ of GDX + T male urine applied to their backs. Gonadectomy, group housing, and social defeat of subordinates reduce offensive aggression in mice, while GDX + T male urine provides subjects with a cue that elicits offensive aggression $[51,58,59]$. Subordinate stimulus males were placed in the subject's home cage and removed after the subject's first offensive attack (biting) within a 10 -min period. All subject males attacked the intruder male stimulus by the second encounter, and all subordinate stimulus males displayed submissive behavior, defined as defensive postures (e.g., on-back postures, fleeing, and non-social exploring [60]). Female subjects were exposed to a female intruder; however, this did not elicit attacks from either animal.

\section{Experimental Procedure}

All testing occurred within the first $8 \mathrm{~h}$ of the dark cycle under red light illumination, with the exception of the elevated plus maze (EPM). All tests were scored by an experimenter blind to the genotype of the subject, and testing occurred across multiple cohorts of subjects. Three to four weeks after viral injections, subjects were habituated to the testing room and apparatus by handling and placing mice (for $5 \mathrm{~min}$ ) in the three-chamber apparatus (see below) each day for 3 days. On experimental days, subjects were adapted to the experimental room for $15 \mathrm{~min}$ prior to testing. First, we tested mice on an EPM to test for anxiety-related behavior [61]. Mice were then tested in the three-chamber apparatus (Fig. 2a) over 6 days with 2-7 days between testing. Lastly, odor discrimination, copulatory, and aggressive behavior were measured sequentially, with a day in between, in the subject's home cage (Fig. 2b, timeline). Female subjects were tested irrespective of estrous cycle day, except during copulation testing, when they were in behavioral estrus. Prior research indicates minimal effects of estrous cycle on female mouse communicative behavior [62-64]. Following testing, subjects were killed, and their brain tissue was processed for in situ hybridization to detect AVP- or oxytocin (OT)-expressing cells within the PVN.

\section{Social Behavior}

USV, urine marking, and social investigation were recorded in an acrylic three-chamber apparatus (Harvard Apparatus, Holliston, MA, USA; dimensions: $20.3 \times 42 \times 22 \mathrm{~cm}$ ) [65-67]. Instead of a solid floor, the apparatus was placed on absorbent paper (Nalgene Versi-dry paper; Thermo Fisher Scientific, Waltham, MA, USA) to accurately measure urine marking. Animals were also tracked using motion detection software (ANY-maze; San Diego Instruments, RRID:SCR_014289). During testing with stimulus animals, subjects had access to either a stimulus animal in a cylindrical cage $(8 \mathrm{~cm}[\mathrm{D}], 18 \mathrm{~cm}[\mathrm{H}] ; 3-\mathrm{mm}$ diameter steel bars, $7.4 \mathrm{~mm}$ spacing) or an empty cage placed at opposite cor- 


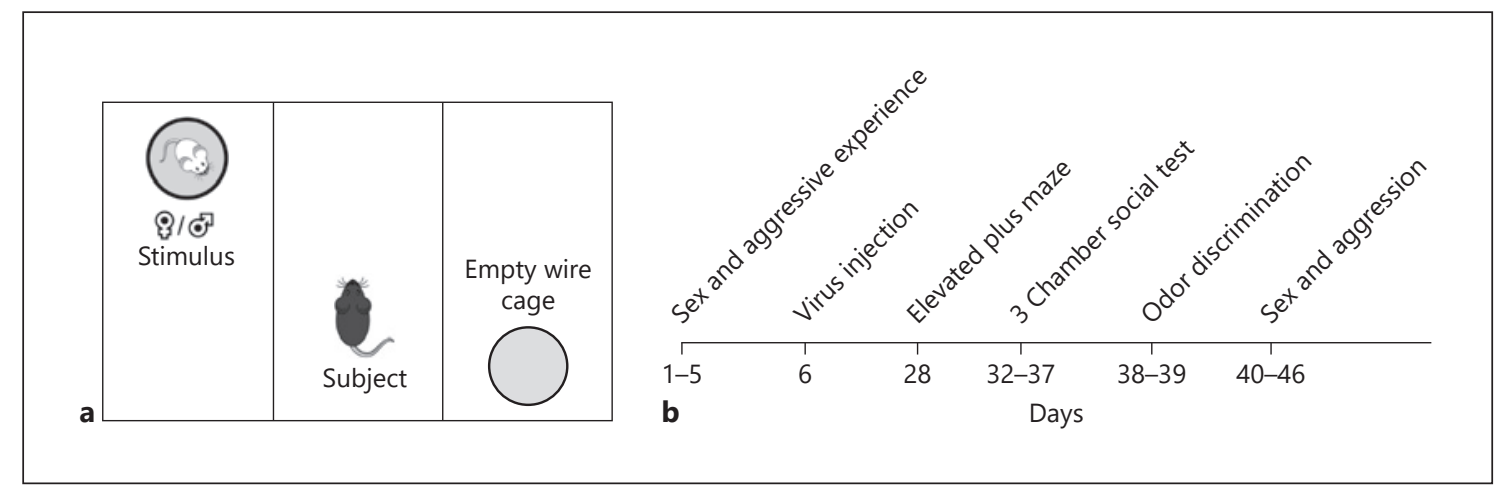

Fig. 2. a Three-chamber social testing. b Experimental timeline.

ners of the outermost chambers of the apparatus. For testing with social odors, subjects had access to $50 \mu \mathrm{L}$ of fresh urine from a stimulus animal or $50 \mu \mathrm{L}$ saline pipetted onto a clean piece of filter paper $\left(3 \mathrm{~cm}^{2}\right)$ that was taped on the outside of cages. The location of stimulus and the "clean" cage were counterbalanced across animals. After placing the subject in the center of the middle chamber, we measured, across a 5 -min trial, close investigation of clean and stimulus cages, distance traveled throughout the apparatus, as well as USV and urine marking, as described below. After testing, the apparatus and cages were thoroughly cleaned with $70 \%$ ethanol and allowed to dry before further testing. In all cases, urine stimulus from one sex was presented first (day 1), followed by a live stimulus of that same sex on the following day (day 2); this order was then repeated 3-5 days later for the opposite sex. In this fashion, mice first experienced a weak stimulus (urine), then a stronger social stimulus (live animal). The order of male and female stimuli presentation was counterbalanced across subjects.

\section{Investigation and USV}

Close investigation was defined as time spent sniffing within $2 \mathrm{~cm}$ of the stimulus or clean cage; climbing on the cage was not scored as investigation. USV were detected using a condenser microphone connected to an amplifier (UltraSoundGate CM16/ CMPA, $10-200 \mathrm{kHz}$, frequency range) placed $4 \mathrm{~cm}$ inside the apparatus and directly above the center compartment. USV were sampled at $200 \mathrm{kHz}$ (16-bit) with target frequency set to $70 \mathrm{kHz}$ (UltraSoundGate $116 \mathrm{Hb}$, Avisoft Bioacoustics, Berlin, Germany). Recordings were then analyzed using a MATLAB (MATLAB, Mathworks, RRID:SCR_001622) plug-in that automates USV analysis [68]. Using this program, sonograms were generated by calculating the power spectrum on Hamming-windowed data and then transformed into compact acoustic feature representations (Gammatone Filterbank). Each 200-ms window containing the maximum USV syllable duration was then clustered, via machine learning algorithms, into USV syllable types (repertoire units) based on time-frequency USV shape. Repertoire units that appeared as background noise were discarded. We counted the number of all USV produced by each subject. USV syllable types were identified using criteria previously described: short, composite, downward, upward, one frequency jump, modulated, multiple frequency jumps, u-shape, flat, chevron [69].

PVN AVP and Social Communication and Behavior in Mice

\section{Urine Marking}

Following testing, the substrate sheet was allowed to dry for $1 \mathrm{~h}$ and then sprayed with ninhydrin fixative (LC-NIN-16; Tritech Forensics Inc., Southport, NC, USA) to visualize urine marks [70, 71]. After $24 \mathrm{~h}$, sheets were imaged (Sony DSC-S700 camera), binarized, and analyzed using computer-aided imaging software (ImageJ, RRID:SCR_003070). Urine marking was measured as the total area (pixels) of visualized ninhydrin urine marks in the entire arena. Urine marks that were larger than $6 \mathrm{~cm}^{2}$ and directed toward corners were counted as elimination "pools" and were counted separately [72].

\section{Copulatory and Aggressive Behavior}

To measure copulatory behavior, the stimulus mouse was placed in the subject's home cage and then removed after $90 \mathrm{~min}$ had elapsed. The latency to mount, percent of females that were mounted, percent of male ejaculations, and number of mount rejections (female kicking male off during mounting attempt) in female subjects was recorded. To measure territorial aggression, subordinate stimulus males were placed in the subject's home cage and then removed after the subject's first offensive attack (biting) within a 10 -min period; the latency to first bite was recorded.

\section{Elevated-Plus Maze}

The EPM consisted of two open arms $(30 \times 5 \times 0 \mathrm{~cm})$ and two closed arms $(30 \times 5 \times 25 \mathrm{~cm})$ crossed perpendicularly and raised $60 \mathrm{~cm}$ above the floor. Subjects were placed at the arm intersection facing the open arm and were habituated to the apparatus for $1 \mathrm{~min}$; subjects were then observed for an additional $5 \mathrm{~min}$. Time spent in open and closed arms and the number of risk assessment behaviors (stretch attend posture, head dips) were manually scored from video [73]. Subjects were removed from EPM data analysis if they fell off the EPM during testing.

\section{Odor Discrimination}

We used a habituation-discrimination approach to test whether subjects could distinguish between social and non-social odors, as described previously $[34,74]$. Briefly, we used the subject's natural tendency to decrease investigation to repeated, familiar odors and to then increase it toward novel odors. We operationally defined odor discrimination as a statistically significant difference between time sniffing the last familiar odor and the novel odor sample. 


\section{Histology and in situ Hybridization}

Following testing, subjects were killed via $\mathrm{CO}_{2}$ asphyxiation. Brains were extracted and flash-frozen via submersion in 2-methyl-2-butanol (Sigma, St. Louis, MO, USA) for 10-20 s and stored at $-80^{\circ} \mathrm{C}$ until sectioned. Coronal sections $(20 \mu \mathrm{m})$ were cut with a cryostat (Leica CM3050 S; Leica Biosystems, Heidelberg, Germany) into 3 series and stored at $-80^{\circ} \mathrm{C}$. All tissue was handled in a RNase-free environment. Tissue was post-fixed in paraformaldehyde, followed by a wash in $2 \times$ saline-sodium citrate (SSC) and acetylation in a triethanolamine/acetic anhydride solution, rinsed in $\mathrm{dH} 20$, washed in acetone/methanol solutions (1:1), and again in $2 \times$ SSC. Tissue was first incubated at $65^{\circ} \mathrm{C}$ in hybridization buffer (50\% deionized formamide, $1 \%$ yeast tRNA, 10\% dextran sulphate, $1 \times$ Denhardt's solution, $5 \% 20 \times$ SSC) for $30 \mathrm{~min}$ before probe application. Riboprobes were developed from linearized PK Bluescript SK(+) with inserted mouse-vasopressin or OT gene (AVP: NM_027106.4, OT: NM_011025.3, Genscript) using digoxygenin (DIG)-conjugated uracil. Riboprobe synthesized from this plasmid was added to the hybridization buffer at a concentration of $100 \mathrm{ng} / 100 \mu \mathrm{L}$ and denatured at $90^{\circ} \mathrm{C}$ for $5 \mathrm{~min}$. Tissue was then hybridized at $65^{\circ} \mathrm{C}$ for $24 \mathrm{~h}$ in a humid chamber. The tissue was then subjected to two 10 -min washes in $2 \times$ SSC at room temperature followed by a $15-$ min digestion with RNase $\mathrm{A}(10 \mathrm{~g} / \mathrm{mL}$ in $2 \times$ SSC) at $37^{\circ} \mathrm{C}$. This was followed by a $30-\mathrm{min} 2 \times \mathrm{SSC}$ wash at $56^{\circ} \mathrm{C}$ and two $10-\min 2 \times$ SSC washes at room temperature. The tissue was then quenched in $1 \% \mathrm{H}_{2} \mathrm{O}_{2}$ in $1 \times \mathrm{SSC}$ for $15 \mathrm{~min}$, rinsed twice in $1 \times$ SSC with $0.1 \%$ Tween followed by one 5 -min TBS $(20 \mathrm{mM}$ Tris, $150 \mathrm{~mm} \mathrm{NaCl}, \mathrm{pH}$ 7.6) wash. Blocking solution (normal sheep serum and bovine casein) was applied, and tissue was incubated for $30 \mathrm{~min}$ followed by 2 -h, room temperature incubation with anti-DIG-HRP (1:200; Roche Applied Sciences, Penzberg, Germany). Unbound antibody was washed away with three 10 -min washes in TBS-T (0.05\% Tween in TBS). DIG-labeled probe signal was amplified and visualized using a TSA Plus Fluorescein kit (Perkin Elmer, Waltham, MA, USA) by incubating sections in a 1:50 dilution of the fluorescein working solution for $12 \mathrm{~min}$ followed by three 10-min washes in TBS. Tissue was then coverslipped using Prolong Gold (Life Technologies, Carlsbad, CA, USA) for subsequent imaging and tissue analysis. Tissue processed using sense RNA probe generated no specific labeling.

\section{Tissue Analysis}

Bilateral images were taken at $10 \times$ magnification using a Zeiss Axio Imager.M2 microscope (Carl Zeiss Microimaging, Göttingen, Germany), which transferred fluorescent images (FITC contrast reflector) to image analysis software (Stereo Investigator, $\mathrm{Mi}$ croBrightField, RRID:SCR_002526). Imaging domains $\left(2 \mathrm{~mm}^{2}\right)$ were placed with reference to anatomical landmarks (ventricles) [48], and the number of fluorescent cells per $\mathrm{mm}^{2}$ was reported. For each subject, fluorescently labeled AVP or OT mRNA-expressing cells were counted in the PVN in both hemispheres across four sections covering the extent of the AVP or (in a smaller subset of subjects: Cre- $[n=3]$ and Cre $+[n=4]$ males and Cre- $[n=4]$ and Cre $+[n=3]$ females) OT cell population (from bregma: -0.58 $\mathrm{mm},-0.70 \mathrm{~mm},-0.82 \mathrm{~mm},-0.94 \mathrm{~mm})$, summed and averaged across each hemisphere, with left and right hemisphere cell averages combined into an overall PVN cell averages and compared across ablated and control subjects. Ablated subjects were included in the analysis if they had $>60 \%$ AVP-expressing cell ablation bilaterally throughout the entire rostral-caudal extent of the nucleus.
In addition, we counted AVP-labeled cells in the nearby mouse accessory area to determine if AVP-expressing cell deletion spread beyond the PVN.

\section{Statistical Analysis}

All data were analyzed and graphed in R (3.4.4; R Core Team, 2017). Histology, social investigation, movement, urine marking, USV, and EPM data met the assumptions of parametric statistical tests. Therefore, we analyzed data on histology, social investigation, movement (distance travelled), time spent in open/closed arms in the EPM test, and urine marking with mixed-model ANOVAs with genotype (Cre+, Cre-) and sex (male, female) as between-subject factors; and sex of stimulus (male, female) and stimulus location (stimulus cage, clean cage) as within-subject factors: followed by $t$ tests using Bonferroni correction assessing genotype effects. Effects of genotype on additional anxiety behaviors (stretch attend, head dips) were analyzed using $t$ tests. Measures of copulatory behavior, and aggression behavior were not normally distributed and could not be transformed; therefore, we analyzed genotype effects on these behaviors using Kruskal-Wallis tests. All post hoc comparisons report Bonferroni-corrected $p$ values and Cohen's $d$ for effect size when statistically significant $(p<0.05)$.

\section{Results}

\section{Histology}

Injections of a viral vector encoding a Cre-dependent cell-death construct into the PVN substantially reduced AVP mRNA-expressing cells in both Cre+ males and females compared to Cre- subjects $(F(1,44)=183.9, p<$ $0.00001)$. Cre+ males showed a $79 \%$ reduction in AVP cells $(t(25)=9.85, p<0.00001, d=3.62)$ and Cre+ females showed a $85 \%$ reduction in AVP cells $(t(18)=9.132, p<$ $0.00001, d=4.29$ ) compared to Cre-controls (Fig. 1b). Although there was a trend toward a significant interaction $(F(1,44)=3.86, p=0.056)$, probably due to females having more AVP mRNA-expressing cells in the Crecontrols and fewer in the Cre+ mice, post hoc tests did not reveal a significant difference in the amount of cells deleted in males compared to females $(t(22)=1.89, p=$ $0.19)$, and no sex difference in the number of PVN AVPexpressing cells in control animals $(t(21)=1.47, p=0.31)$. Ablations of PVN AVP-expressing cells did not significantly reduce the number of OT mRNA-expressing cells $(F(1,10)=0.7, p=0.36$; males: $t(5)=1.03, p=0.35$; females: $t(5)=0.12, p=0.9$, Fig. $1 c, e)$ or reduce the number of AVP mRNA-expressing cells in the nearby hypothalamic/mouse accessory area (data not shown), suggesting no significant off-target cell deletions. Additionally, all anterior-posterior levels of the PVN had significant bilateral reduction in AVP cell number (online suppl. Fig. 1; see www.karger.com/doi/10.1159/000509421 for all on- 


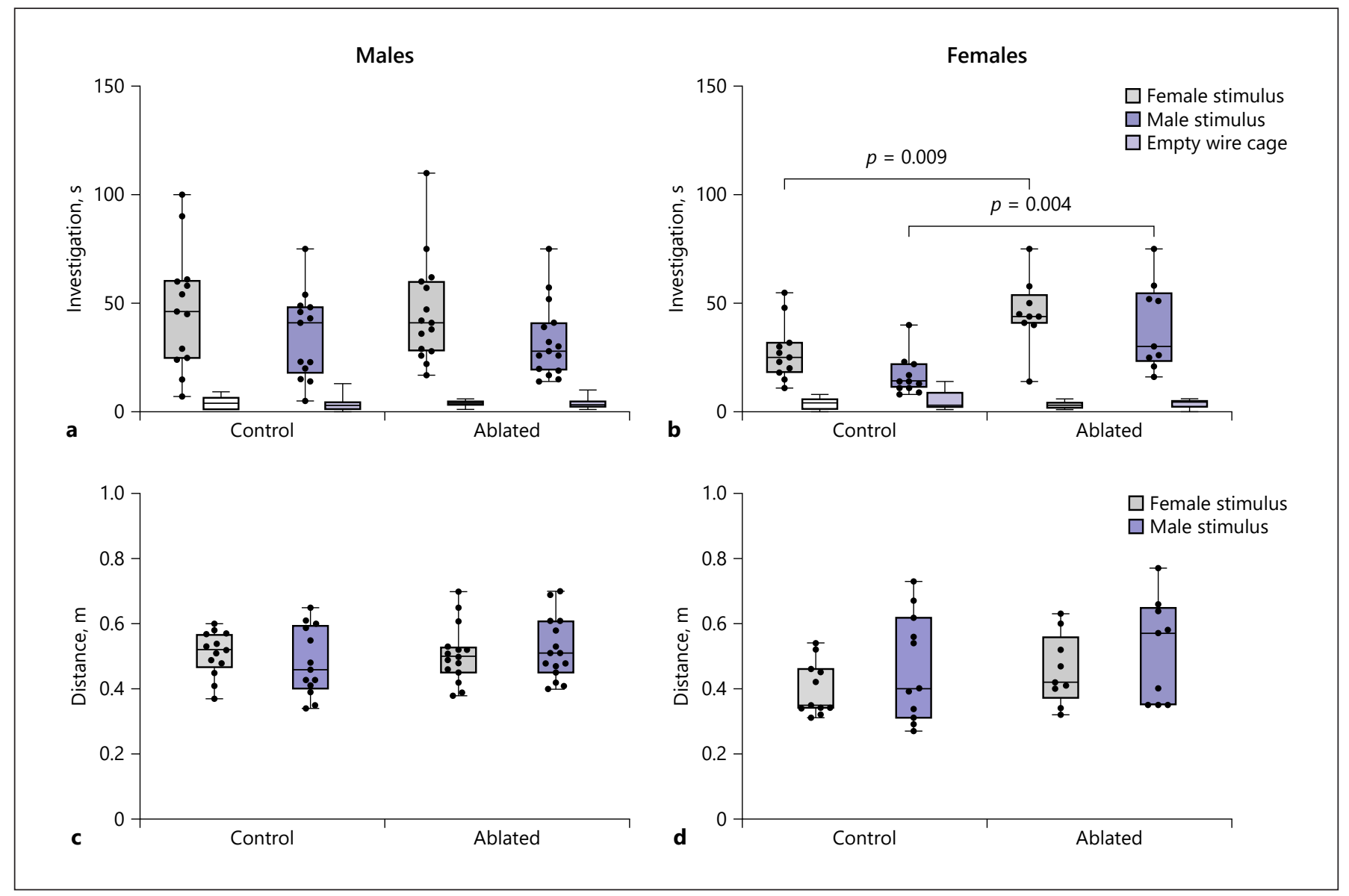

Fig. 3. PVN AVP-expressing cell ablations increase social investigation by females. a, b Boxplots indicating individual data points, median, first and third quartiles for time spent investigating wire cages with male or female stimulus animals, or an empty wire cage within the three-chamber apparatus. PVN AVP-expressing cell

line suppl. material), indicating no systematic bias in targeted cell death within the PVN. Cre+ subjects that had $<60 \%$ cell deletion (bilaterally) were removed from the analysis (5 males and 4 females).

\section{PVN AVP-Expressing Cell Ablations in Females Increase Social Investigation}

All subjects investigated cages with stimulus animals more than the empty cages $(F(1,44)=208.5, p<0.00001)$. Overall, there was a significant difference between genotypes $(F(1,44)=4.38, p=0.04)$ as well an interaction between sex and genotype $(F(1,44)=5.33, p=0.02)$. Control males showed higher levels of investigation than did control females (female stimulus: $t(22)=2.15, p=0.046, d=$ 0.9 ; male stimulus: $t(22)=2.90, p=0.001, d=1.22)$; ablation of PVN AVP-expressing cells, however, removed this sex ablations in females (b), but not males (a), significantly increased investigation of female $(p=0.009)$ and male $(p=0.004)$ stimuli compared to controls. $\mathbf{c}, \mathbf{d}$ Control and AVP-expressing cell-ablated subjects did not differ in distance traveled within the threechamber apparatus. difference (female stimulus: $t(22)=0.1, p=0.9$; male stimulus: $t(22)=0.8, p=0.41)$. Removing PVN AVP-expressing cells in females increased investigation of cages with male as well as female stimulus animals (female stimulus: $t(26)=2.92, p=0.009, d=1.3$; male stimulus: $(t(18)=3.36$, $p=0.004, d=1.4$; Fig. $3 \mathrm{~b})$, whereas ablations in males did not (male stimulus: $t(26)=0.1, p=0.93$; female stimulus: $t(26)=0.13, p=0.9$; Fig. 3a). AVP-expressing cell deletion did not alter investigation of filter paper with urine $(F(1,44)=0.002, p=0.97$, online suppl. Table 1$)$. Males and females of both genotypes were able to discriminate between male and female urine odors (data not shown).

Although males were more active than females $(F(1,44)=4.6, p=0.038)$, there were no significant overall differences in activity between control and ablated subjects $(F(1,44)=3, p=0.09$, Fig. $3 c$, d), nor were there 
interactions between genotype and $\operatorname{sex}(F(1,44)=0.7, p=$ $0.4)$, or genotype and sex of stimulus animal $(F(1,44)=$ $0.15, p=0.7)$. Consequently, PVN AVP-expressing cell ablations do not grossly alter locomotor behavior.

\section{PVN AVP-Expressing Cell Ablations Did Not Alter}

\section{Social Communication}

Male subjects urine-marked more than females, but PVN AVP-ablated and control did not differ in urine marking within the three-chamber apparatus $(F(1,44)=$ $2.01, p=0.16$, Table 1 ). Only 2 male mice (both Cre- controls) urinated in an elimination "pool" (one to a female stimulus, the other to a male stimulus; both in a corner); these pools were not counted as urine marks. Similarly, males produced more USVs than females, specifically toward female stimuli $(F(1,44)=6.78, p=0.01)$, but overall AVP cell-ablated and control subjects did not differ in the amount of USVs emitted $(F(1,44)=0.02, p=0.88$, Table $1)$ or in the types of syllables produced $(F(1,44)=0.4, p=$ 0.54 , online suppl. Fig. 2). Subjects did not differ in urine marking $(F(1,44)=0.81, p=0.37)$ or USVs $(F(1,44)=1.4$, $p=0.24$ ) in the presence of male or female urine (online suppl. Table 1).

\section{PVN AVP-Expressing Cell Ablations in Males, but}

\section{Not Females, Increase Anxiety-Like Behavior}

We measured time spent in the open, anxiogenic, arms along with risk assessment postures (stretch attends, head dips) in the EPM. Six males (2 control, 4 cell-deleted) and one control female fell off the EPM during testing and so their data are not included in the EPM analysis. Overall, there were no sex differences in time spent in the open arms $(F(1,37)=0.3, p=0.57)$ or in frequency of risk assessment behaviors (stretch attends: $F(1,37)=0.03, p=$ 0.85 ; head dips: $(F(1,37)=3.1, p=0.09)$. There was a trend toward a main effect of genotype in time spent in the open $\operatorname{arms}(F(1,37)=3.4, p=0.07)$ with an interaction between genotype and sex of subject for stretch attends $(F(1,37)=$ $5.9, p=0.02)$. Post hoc analysis revealed male subjects with PVN AVP cell ablations decreased the amount of time spent in the open arms of the EPM $(t(20)=2.27, p=$ $0.034, d=0.96$, Fig. $4 \mathrm{a}$ ), increased the amount of stretch attend postures $(t(20)=3.66, p=0.002, d=1.56$, Fig. $4 \mathrm{c})$, and trended toward an increase in the amount of head $\operatorname{dips}(t(20)=1.82, p=0.08, d=0.78$, Fig. $4 \mathrm{e})$ compared to controls. PVN AVP cell-ablated female subjects did not differ from controls on any anxiety-like behaviors in the EPM (time spent in open arm: $t(17)=0.49, p=0.63$; stretch attends: $t(17)=1.38, p=0.19$; head dips: $t(17)=$ $0.42, p=0.68$; Fig. 4b, d, f). 


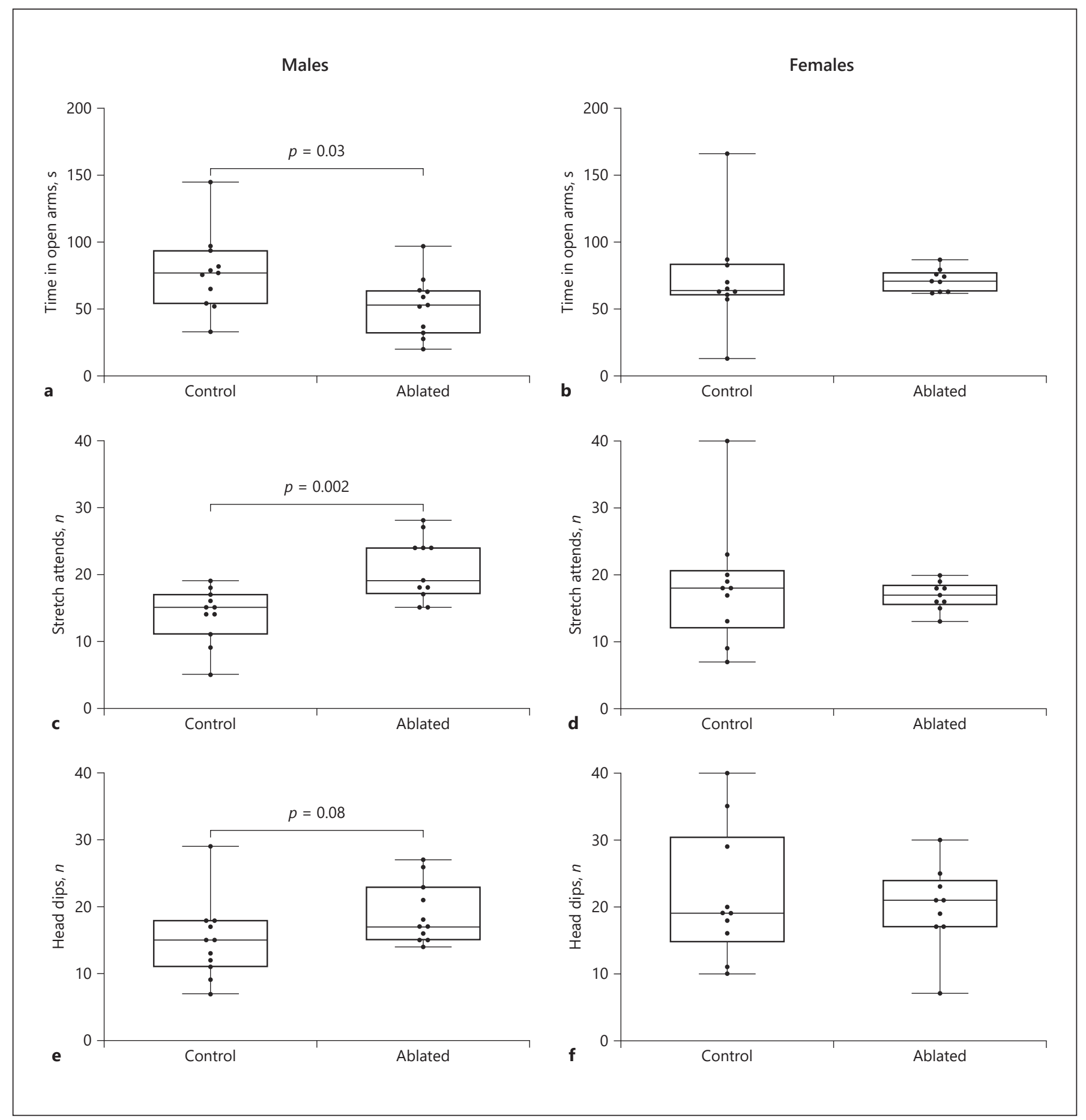

Fig. 4. PVN AVP-expressing cell ablations in males increase anxiety-like behavior. Boxplots indicating individual data points, median, first, and third quartiles for time spent in the open arms within the EPM, number of stretch attend postures, and number of head dips. Males with PVN AVP-expressing cell ablations increased time spent in open arms $(\mathbf{a} ; p=0.03)$, whereas females with
PVN AVP-expressing cell removal did not differ from controls (b). Similarly, lesioned males $(\mathbf{c})$, but not females $(\mathbf{d})$, produced more stretch attend postures than controls $(p=0.002)$. Cell-ablated males (e), but not females (f), trended toward increasing head dips $(p=0.08)$ compared to controls. 


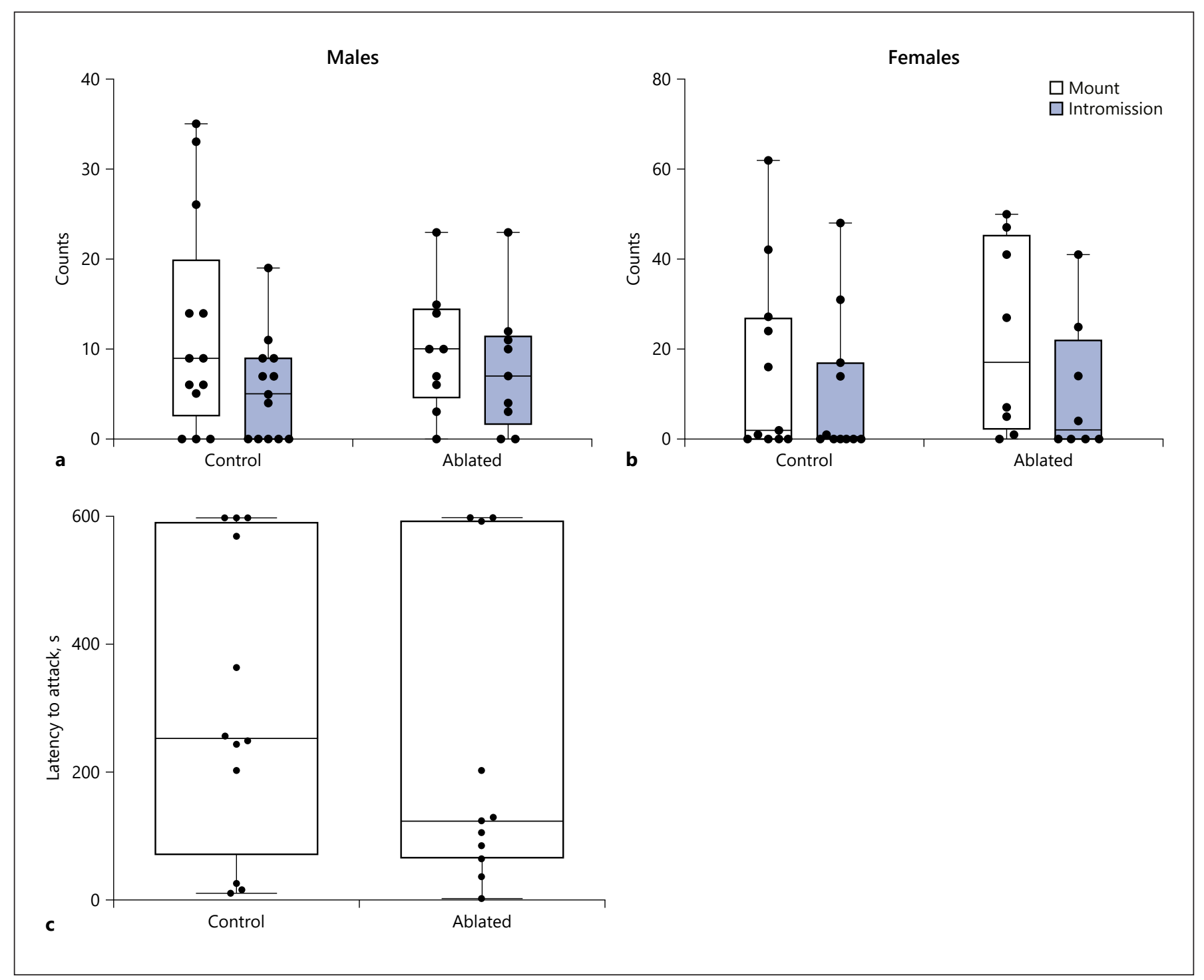

Fig. 5. PVN AVP-expressing cell ablations did not alter copulatory or aggressive behavior. Boxplots indicating individual data points, median, first, and third quartiles for the number of mounts and intromissions performed by male subjects (a) and the number of mounts and intromissions received by females (b). No differences were found in these measures. c No differences were found either in latency to attack an intruder male between control and celldeleted males.

\section{PVN AVP-Expressing Cell Ablation Does Not Alter} Copulatory or Aggressive Behavior

Cell-ablated males did not differ from controls in the number of mounts $(\mathrm{H}=0.02, p=0.89)$ or intromissions $(\mathrm{H}=0.4, p=0.52)$ targeted toward females (Fig. 5a). Similarly, lesioned females did not differ from controls in the number of mounts $(\mathrm{H}=1, p=0.32)$ or intromissions $(\mathrm{H}=0.2, p=0.89)$ received from males (Fig. $5 b)$. There were no differences between controls and PVN AVP-expressing cell-ablated males in their latency to attack intruders $(\mathrm{H}=0.6, p=0.81$, Fig. $5 \mathrm{c})$. Females, regardless of condition, did not fight during same-sex interactions.

\section{Discussion}

Our results indicate that PVN AVP-expressing cells may contribute to sexually dimorphic components of social behavior and anxiety, because PVN AVP-expressing 
cell ablations increased social investigation (of same as well as opposite-sex conspecifics) in females, but not in males. However, in males but not in females, these lesions increased non-social, anxiety-related behaviors. These results point to differential involvement of PVN AVPexpressing cells in the control of social and emotional behavior in the 2 sexes.

The effect of PVN AVP lesions on social investigation and anxiety-like behaviors may be the result of other, more general, changes in behavior. This is unlikely, however, because these lesions did not affect other communicative behaviors, general activity, territorial aggression, and sexual behavior. Moreover, the effects of our PVN AVP-expressing cell ablations are not likely to be caused by off-target effects, as we did not observe differences in expression of OT, a related neuropeptide, in the PVN between lesioned and control animals or AVP-expressing cell deletion in nearby hypothalamic areas.

Our experiments do not allow us to conclude that removal of AVP itself within the PVN caused the behavioral effects observed in this study. Ablating AVP-expressing cells in the PVN also removed all other neuroactive substances co-expressed, produced, and secreted by these cells, which may have caused the behavioral results we observed. For example, female rodents have more ER $\beta$ in PVN AVP-expressing cells than males [75, $76]$, and global ER $\beta$ knockout increases social investigation by females preferentially [77, 78]. Consequently, our effects may be due to removal of sexually dimorphic signaling mediated by ER $\beta$ or other molecules in PVN cells.

Our experiments also do not allow us to identify which AVP-expressing cells may have contributed to our results. The PVN contains at least three different sets of AVP-expressing cells, magnocellular cells that project to the posterior pituitary, corticotropin-releasing factor (CRF) cells that may co-express AVP and project to the median eminence, and non-neurosecretory AVP-expressing cells that project to other brain areas $[28,79]$. In principle, all of these cells may have been deleted in our Cre+ mice, and possible effects may therefore be attributed to central as well as peripheral effects. As our animals did not show differences in water uptake (data not shown) or in urination (urine marking) patterns, the reduction in peripheral AVP derived from the PVN may have been compensated by AVP secreted from supraoptic neurosecretory cells. A loss of CRF cells may, in principle, have changed the function of the HPA axis, which may have contributed to our results. However, the overlap of CRF and AVP is about $10 \%$ in unstressed mice [79], suggesting

PVN AVP and Social Communication and Behavior in Mice that ablation of these cells might have minimal effect on the HPA axis. In addition, mice genetically altered to specifically remove CRF cells in the PVN show reduced anxiety [80], while removal of AVP-expressing cells in the $\mathrm{PVN}$ in the current study produced an increase in anxiety. It is also possible that AVP within the PVN can be released by dendrites, and therefore our results may be due to disruption of local dendritic release [81]. Lastly, centrally projecting AVP cells of the PVN innervate a distinct set of targets within the brain [30], and removal of these cells would deprive their targets of AVP input. Therefore, both removal of dendritically and axonally released AVP and potentially other neuroactive substances produced by AVP-expressing cells in the PVN may have contributed to our results.

An additional caveat is that our results may reflect molecular, cellular, and anatomic adjustments or compensations to chronic depletion of AVP-expressing cells in the PVN. Indeed, long-term pharmacological reduction of $\mathrm{V} 1 \mathrm{a}$ receptor (V1aR) activity in the lateral septum, a target of AVP-expressing cells in the PVN [38], increases anxiety-like behavior, while acute V1aR blockade in this region has the opposite effect $[82,83]$. A lack of an effect on a behavior, therefore, does not completely exclude involvement of these cells in acute regulation of these behaviors; this could be addressed in future studies using acute chemogenetic or optogenetic techniques.

It is surprising that ablation of AVP-expressing cells in the PVN increased anxiety-like behaviors in the EPM in males, since most studies point at central AVP stimulating, not inhibiting, these behaviors [19-23]. In addition, male or female rats and mice bred for high levels of trait anxiety show higher AVP expression in the PVN [84-86]. However, we note that these findings supporting a positive relationship between brain AVP and anxiety are correlational. In fact, other findings indicate that decreased PVN AVP expression correlates with increased anxiety in isolation-reared male, but not female rats [87]. Importantly, direct AVP manipulations such as intracerebroventricular AVP administration or knockdown of AVP expression in the PVN have produced no effects on anxiety-like behavior $[41,88]$. Our results, however, indicate that PVN AVP-expressing cells appear to be important for the regulation of anxiety, but more so in males than in females.

Deleting PVN AVP-expressing cells elevated conspecific investigation in females, but not males, indicating that these cells are more important modulators of social investigation in females than in males. The fact that PVN AVP-expressing cell deletion had no effect on male social 
investigation is somewhat surprising given that low AVP mRNA within PVN is correlated with less time social investigating other males [39]. However, other findings indicate that chronic variable stress decreases female AVP mRNA in PVN and increases female social investigation of other females, while not affecting males, perhaps due to higher stress resilience in males [40]. In combination with our previous work demonstrating that BNST AVPexpressing cells are important for male, but not female, social investigation of other males [34], the present findings suggest that males and females may use different AVP circuitry for modulating social investigation. Interestingly, they also point at AVP-expressing cells in the $\mathrm{PVN}$ as an important factor in the sex difference in social investigation, with males showing higher levels of investigation than do females, observed in the present study and in others [89-92], as removal of these cells removed the sex difference as well.

Ablations of AVP-expressing cells in the PVN did not significantly alter the production of USV s or urine marking, suggesting these cells are not necessary for all social communicative behaviors. Although AVP has been implicated in the production of vocalizations [7], few studies have identified the relevant neuroanatomical source of AVP or its locus of action. Recently, we found that blockade of $\mathrm{V} 1 \mathrm{aR}$ in the lateral habenula reduced male courtship USVs in mice [9] but that BNST AVP-expressing cell deletion did not affect USVs [34]. Therefore, it is likely that AVP sources outside the PVN and the BNST, such as the MA, play the lead role in driving USV production. We did find BNST AVP-expressing cell ablations influence other communicative behaviors, such as urine marking; therefore, AVP signals originating from sexually dimorphic structures such as the BNST or MA may be more important for male communication than AVP from the PVN [34].

Ablations of AVP-expressing cells in the PVN did not significantly alter aggression. While pharmacological studies suggest that several structures, such as the anterior hypothalamus, ventromedial hypothalamus, and lateral septum receive AVP input that facilitates aggressive behavior [93-95], our finding that PVN AVP-expressing cell deletions did not alter territorial aggression does not support the idea that the PVN is the source of AVP that facilitates aggression. This is in agreement with the lack of a reduction in aggression following AVP knockdown in the PVN of birds [41]. Other hypothalamic AVP-expressing cell groups unaffected by our lesions, like the nucleus circularis, may be driving pro-aggressive effects of AVP [96-98].
There are several reasons why the effects of PVN AVPexpressing cell ablations may have had sexually dimorphic effects on anxiety and social behavior. The first is that these cells are inherently dimorphic. For example, AVP projections from the PVN are denser in females than in males [38]. One may therefore expect that removal of these projections would have a larger effect on behavior in females than in males. Although this is true for social behavior, it was the opposite for anxiety-related behavior. Another reason for sex-different effects is that these cells may project to sexually differentiated targets or to areas whose function may differ in males and females. Indeed, PVN AVP cells project to areas that show sex differences in V1a and OT receptor binding [38], [99], the two receptors that mediate behavioral effects of AVP [100]. In addition, some target areas of PVN AVP-expressing cells, such as the locus coeruleus [38], which has been implicated in the control of anxiety [101], show different physiological responses, even to similar afferent stimulation [102]. Sex differences like this may have contributed to the sex-biased effects of removal of PVN AVPexpressing cells on anxiety, which were present in males, but not in females.

Our previous work has identified the sexually dimorphic AVP-expressing cells in the BNST as contributors to sex differences in social behavior, especially for social investigation and communication [34]. The present study demonstrates that AVP-expressing cells in the PVN can also modulate social interactions, as well as anxiety, but do so independently and in a sex-dependent manner.

\section{Acknowledgment}

We thank Michael Hohl, Rachael Beaumont, and Andrew Anello for their assistance collecting behavioral and histological data and Dr. Geert J. de Vries for helpful comments on the manuscript.

\section{Statement of Ethics}

All experimental procedures were reviewed and approved by Institutional Animal Care and Use Committee (IACUC) of Georgia State University.

\section{Conflict of Interest Statement}

The authors declare no conflicts of interest. 


\section{Funding Sources}

This work was supported by National Institutes of Health (R21 MH111104).

\section{References}

1 Choleris E, Clipperton-Allen AE, Phan A, Kavaliers $M$. Neuroendocrinology of social information processing in rats and mice. Front Neuroendocrinol. 2009 Oct;30(4):442-59.

2 Donaldson ZR, Young LJ. Oxytocin, vasopressin, and the neurogenetics of sociality. Science. 2008 Nov;322(5903):900-4.

3 Insel TR. The challenge of translation in social neuroscience: a review of oxytocin, vasopressin, and affiliative behavior. Neuron. 2010 Mar;65(6):768-79.

4 Caldwell HK. Oxytocin and Vasopressin: Powerful Regulators of Social Behavior. Neuroscientist. 2017 Oct;23(5):517-28.

5 Guastella AJ, Kenyon AR, Alvares GA, Carson DS, Hickie IB. Intranasal arginine vasopressin enhances the encoding of happy and angry faces in humans. Biol Psychiatry. 2010 Jun;67(12):1220-2.

6 Rilling JK, DeMarco AC, Hackett PD, Chen X, Gautam P, Stair S, et al. Sex differences in the neural and behavioral response to intranasal oxytocin and vasopressin during human social interaction. Psychoneuroendocrinology. 2014 Jan;39:237-48.

7 Goodson JL, Bass AH. Social behavior functions and related anatomical characteristics of vasotocin/vasopressin systems in vertebrates. Brain Res Brain Res Rev. 2001 Jul;35(3):24665.

8 Kelly AM, Goodson JL. Behavioral relevance of species-specific vasotocin anatomy in gregarious finches. Front Neurosci. 2013 Dec;7: 242.

9 Rigney N, Beaumont R, Petrulis A. Sex differences in vasopressin 1a receptor regulation of social communication within the lateral habenula and dorsal raphe of mice. Horm Behav. 2020 May;121(Feb):104715.

10 Bosch OJ, Neumann ID. Brain vasopressin is an important regulator of maternal behavior independent of dams' trait anxiety. Proc Natl Acad Sci USA. 2008 Nov;105(44):17139-44.

11 Carter CS, DeVries AC, Getz LL. Physiological substrates of mammalian monogamy: the prairie vole model. Neurosci Biobehav Rev. 1995;19(2):303-14.

12 Young LJ, Wang Z. The neurobiology of pair bonding. Nat Neurosci. 2004 Oct;7(10):104854.

13 Jarcho MR, Mendoza SP, Mason WA, Yang X, Bales KL. Intranasal vasopressin affects pair bonding and peripheral gene expression in male Callicebus cupreus. Genes Brain Behav. 2011 Apr;10(3):375-83. 61(1):50-6

\section{Author Contributions}

N.R. designed research, carried out the experiments, performed the data analysis and prepared the manuscript; J.W. carried out the experiments; A.P. and G.J.V. conceived the idea, supervised the research and prepared the manuscript.
14 Landgraf R, Neumann ID. Vasopressin and oxytocin release within the brain: a dynamic concept of multiple and variable modes of neuropeptide communication. Front Neuroendocrinol. 2004 Sep-Dec;25(3-4):150-76.

15 Dantzer R, Koob GF, Bluthé RM, Le Moal M. Septal vasopressin modulates social memory in male rats. Brain Res. 1988 Aug;457(1):143-7.

16 Veenema AH, Bredewold R, De Vries GJ. Vasopressin regulates social recognition in juvenile and adult rats of both sexes, but in sexand age-specific ways. Horm Behav. 2012 Jan;

17 Johnson ZV, Young LJ. Oxytocin and vasopressin neural networks: Implications for social behavioral diversity and translational neuroscience. Neurosci Biobehav Rev. 2017 May;76(Pt A):87-98.

18 Landgraf $\mathrm{R}$. The involvement of the vasopressin system in stress-related disorders. CNS Neurol Disord Drug Targets. 2006 Apr;5(2): $167-79$.

19 Neumann ID, Landgraf R. Balance of brain oxytocin and vasopressin: implications for anxiety, depression, and social behaviors. Trends Neurosci. 2012 Nov;35(11):649-59.

20 Mak P, Broussard C, Vacy K, Broadbear JH. Modulation of anxiety behavior in the elevated plus maze using peptidic oxytocin and vasopressin receptor ligands in the rat. J Psychopharmacol. 2012 Apr;26(4):532-42.

21 Fabio K, Guillon C, Lu S-F, Heindel ND, Miller M, Ferris CF, et al. Vasopressin Antagonists as Anxiolytics and Antidepressants: Recent Developments. Frontiers in CNS Drug Discovery. 2012;156-83.

22 Bielsky IF, Hu SB, Szegda KL, Westphal H, Young LJ. Profound impairment in social recognition and reduction in anxiety-like behavior in vasopressin V1a receptor knockout mice. Neuropsychopharmacology. 2004 Mar; 29(3):483-93.

23 Caldwell HK, Lee HJ, Macbeth AH, Young WS 3rd. Vasopressin: behavioral roles of an "original" neuropeptide. Prog Neurobiol. 2008 Jan;84(1):1-24.

24 Albers HE. Species, sex and individual differences in the vasotocin/vasopressin system: relationship to neurochemical signaling in the social behavior neural network. Front Neuroendocrinol. 2015 Jan;36:49-71.

25 Sawchenko PE, Swanson LW. Immunohistochemical identification of neurons in the paraventricular nucleus of the hypothalamus that project to the medulla or to the spinal cord in the rat. J Comp Neurol. 1982 Mar; 205(3):260-72.
26 Farina-Lipari E, Valentino B. Immunohistochemical research on vasopressin in the accessory hypothalamic nuclei. Ital J Anat Embryol. 1993 Jul-Sep;98(3):207-14.

27 Ring RH. The central vasopressinergic system: examining the opportunities for psychiatric drug development. Curr Pharm Des. 2005;11(2):205-25.

28 De Vries GJ, Panzica GC. Sexual differentiation of central vasopressin and vasotocin systems in vertebrates: different mechanisms, similar endpoints. Neuroscience. 2006; 138(3):947-55.

29 de Vries GJ. Sex differences in vasopressin and oxytocin innervation of the brain. Prog Brain Res. 2008;170:17-27.

30 Rood BD, De Vries GJ. Vasopressin innervation of the mouse (Mus musculus) brain and spinal cord. J Comp Neurol. 2011 Aug; 519(12):2434-74.

31 Tobin VA, Hashimoto $\mathrm{H}$, Wacker DW, Takayanagi Y, Langnaese K, Caquineau C, et al. An intrinsic vasopressin system in the olfactory bulb is involved in social recognition. Nature. 2010 Mar;464(7287):413-7.

32 van Leeuwen FW, Caffe AR, De Vries GJ. Vasopressin cells in the bed nucleus of the stria terminalis of the rat: sex differences and the influence of androgens. Brain Res. 1985 Jan; 325(1-2):391-4.

33 Otero-Garcia M, Martin-Sanchez A, FortesMarco L, Martínez-Ricós J, Agustin-Pavón C, Lanuza E, et al. Extending the socio-sexual brain: arginine-vasopressin immunoreactive circuits in the telencephalon of mice. Brain Struct Funct. 2014 May;219(3):1055-81.

34 Rigney N, Whylings J, Mieda M, de Vries G, Petrulis A. Sexually Dimorphic Vasopressin Cells Modulate Social Investigation and Communication in Sex-Specific Ways. eNeuro. 2019 Jan;6(1):ENEURO.0415-18.2019.

35 Whylings J, Rigney N, Peters NV, de Vries GJ, Petrulis A. Sexually dimorphic role of BNST vasopressin cells in sickness and social behavior in male and female mice. Brain Behav Immun. 2020 Jan;83:68-77.

36 Tschida K, Michael V, Takatoh J, Han BX, Zhao S, Sakurai K, et al. A Specialized Neural Circuit Gates Social Vocalizations in the Mouse. Neuron. 2019 Aug;103(3):459-72.e4.

37 Herman JP, Ostrander MM, Mueller NK, Figueiredo H. Limbic system mechanisms of stress regulation: hypothalamo-pituitary-adrenocortical axis. Prog Neuropsychopharmacol Biol Psychiatry. 2005 Dec;29(8):1201-13.
PVN AVP and Social Communication and Behavior in Mice
Neuroendocrinology 2021;111:521-535 DOI: $10.1159 / 000509421$ 
38 Rood BD, Stott RT, You S, Smith CJ, Woodbury ME, De Vries GJ. Site of origin of and sex differences in the vasopressin innervation of the mouse (Mus musculus) brain. J Comp Neurol. 2013 Jul;521(10):2321-58.

39 Murakami G, Hunter RG, Fontaine C, Ribeiro A, Pfaff D. Relationships among estrogen receptor, oxytocin and vasopressin gene expression and social interaction in male mice. Eur J Neurosci. 2011 Aug;34(3):469-77.

40 Borrow AP, Bales NJ, Stover SA, Handa RJ Chronic Variable Stress Induces Sex-Specific Alterations in Social Behavior and Neuropeptide Expression in the Mouse. Endocrinology. 2018 Jul;159(7):2803-14.

41 Kelly AM, Goodson JL. Hypothalamic oxytocin and vasopressin neurons exert sex-specific effects on pair bonding, gregariousness, and aggression in finches. Proc Natl Acad Sci USA. 2014 Apr;111(16):6069-74.

42 Smith AS, Williams Avram SK, CymerblitSabba A, Song J, Young WS. Targeted activation of the hippocampal CA2 area strongly enhances social memory. Mol Psychiatry. 2016 Aug;21(8):1137-44.

43 Kappel S, Hawkins P, Mendl MT. To Group or Not to Group? Good Practice for Housing Male Laboratory Mice. Animals (Basel). 2017 Nov;7(12):E88

44 Gheusi G, Bluthé RM, Goodall G, Dantzer R. Social and individual recognition in rodents: methodological aspects and neurobiological bases. Behav Processes. 1994 Dec;33(1-2):5987.

45 Yang CF, Chiang MC, Gray DC, Prabhakaran M, Alvarado M, Juntti SA, et al. Sexually dimorphic neurons in the ventromedial hypothalamus govern mating in both sexes and aggression in males. Cell. 2013 May;153(4):896-909.

46 Unger EK, Burke KJ Jr, Yang CF, Bender KJ, Fuller PM, Shah NM. Medial amygdalar aromatase neurons regulate aggression in both sexes. Cell Rep. 2015 Feb;10(4):453-62.

47 Morgan CW, Julien O, Unger EK, Shah NM, Wells JA. Turning on caspases with genetics and small molecules. Methods Enzymol. 2014;544:179-213.

48 Paxinos G, Franklin K. Paxinos and Franklin's the Mouse Brain in Stereotaxic Coordinates - 4th Edition [Internet]. 2012 Oct [cited 2018 Sep 6]. Available from: https://www.elsevier.com/books/paxinos-and-franklinsthe-mouse-brain-in-stereotaxic-coordinates/ paxinos/978-0-12-391057-8.

49 Matochik JA, Sipos ML, Nyby JG, Barfield RJ. Intracranial androgenic activation of maletypical behaviors in house mice: motivation versus performance. Behav Brain Res. 1994 Feb;60(2):141-9.

50 Barkley MS, Goldman BD. The effects of castration and Silastic implants of testosterone on intermale aggression in the mouse. Horm Behav. 1977 Aug;9(1):32-48.

51 Beeman EA. The relation of the interval between castration and first encounter to the aggressive behavior of mice. Anat Rec. 1947 Dec;99(4):570.
52 Bakker J, Honda S, Harada N, Balthazart J. The aromatase knock-out mouse provides new evidence that estradiol is required during development in the female for the expression of sociosexual behaviors in adulthood. J Neurosci. 2002 Oct;22(20):9104-12.

53 Ström JO, Theodorsson A, Ingberg E, Isaksson IM, Theodorsson E. Ovariectomy and $17 \beta$-estradiol replacement in rats and mice: a visual demonstration. J Vis Exp. 2012 Jun; (64):e4013.

54 Veyrac A, Wang G, Baum MJ, Bakker J. The main and accessory olfactory systems of female mice are activated differentially by dominant versus subordinate male urinary odors. Brain Res. 2011 Jul;1402:20-9.

55 Caligioni CS. Assessing reproductive status/ stages in mice. Curr Protoc Neurosci. 2009 Jul; APPENDIX: Appendix-4I.

56 Roullet FI, Wöhr M, Crawley JN. Female urine-induced male mice ultrasonic vocalizations, but not scent-marking, is modulated by social experience. Behav Brain Res. 2011 Jan; 216(1):19-28

57 Lumley LA, Sipos ML, Charles RC, Charles RF, Meyerhoff JL. Social stress effects on territorial marking and ultrasonic vocalizations in mice. Physiol Behav. 1999 Nov;67(5):76975.

58 Connor JL, Winston H. Genetic analysis of conditioned emotional responses in the mouse (Mus musculus L.). J Comp Physiol Psychol. 1972 Oct;81(1):37-44.

59 Van Loo PL, Mol JA, Koolhaas JM, Van Zutphen BF, Baumans V. Modulation of aggression in male mice: influence of group size and cage size. Physiol Behav. 2001 Apr;72(5):67583.

60 Koolhaas JM, Coppens CM, de Boer SF, Buwalda B, Meerlo P, Timmermans PJ. The resident-intruder paradigm: a standardized test for aggression, violence and social stress. J Vis Exp. 2013 Jul;(77):e4367.

61 Lister RG. The use of a plus-maze to measure anxiety in the mouse. Psychopharmacology (Berl). 1987;92(2):180-5.

62 Maggio JC, Whitney G. Ultrasonic vocalizing by adult female mice (Mus musculus). J Comp Psychol. 1985 Dec;99(4):420-36.

63 Coquelin A. Urine-marking by female mice throughout their reproductive cycle. Horm Behav. 1992 Jun;26(2):255-71.

64 Moncho-Bogani J, Lanuza E, Lorente MJ, Martinez-Garcia F. Attraction to male pheromones and sexual behaviour show different regulatory mechanisms in female mice. Physiol Behav. 2004 May;81(3):427-34.

65 Moy SS, Nadler JJ, Young NB, Nonneman RJ, Grossman AW, Murphy DL, et al. Social approach in genetically engineered mouse lines relevant to autism. Genes Brain Behav. 2009 Mar;8(2):129-42.

66 Arakawa H, Arakawa K, Blanchard DC, Blanchard RJ. A new test paradigm for social recognition evidenced by urinary scent marking behavior in C57BL/6J mice. Behav Brain Res. 2008 Jun;190(1):97-104.
67 Crawley JN. Mouse behavioral assays relevant to the symptoms of autism. Brain Pathol. 2007 Oct;17(4):448-59.

68 Van Segbroeck M, Knoll AT, Levitt P, Narayanan S. MUPET-Mouse Ultrasonic Profile ExTraction: A Signal Processing Tool for Rapid and Unsupervised Analysis of Ultrasonic Vocalizations. Neuron. 2017 May; 94(3):465-85.e5.

69 Hanson JL, Hurley LM. Female presence and estrous state influence mouse ultrasonic courtship vocalizations. PLoS One. 2012; 7(7):e40782.

70 Meyer $\mathrm{H}$. The ninhydrin reaction and its analytical applications. Biochem J. 1957 Oct; 67(2):333-40.

71 Lehmann ML, Geddes CE, Lee JL, Herkenham M. Urine scent marking (USM): a novel test for depressive-like behavior and a predictor of stress resiliency in mice. PLoS One. 2013 Jul;8(7):e69822.

72 Bishop MJ, Chevins PF. Urine odours and marking patterns in territorial laboratory mice (Mus musculus ). Behav Processes. 1987 Dec;15(2-3):233-48.

73 Cole JC, Rodgers RJ. An ethological analysis of the effects of chlordiazepoxide and bretazenil (Ro 16-6028) in the murine elevated plusmaze. Behav Pharmacol. 1993 Dec;4(6):57380.

74 Baum MJ, Keverne EB. Sex difference in attraction thresholds for volatile odors from male and estrous female mouse urine. Horm Behav. 2002 Mar;41(2):213-9.

75 Hrabovszky E, Kalló I, Hajszán T, Shughrue PJ, Merchenthaler I, Liposits Z. Expression of estrogen receptor-beta messenger ribonucleic acid in oxytocin and vasopressin neurons of the rat supraoptic and paraventricular nuclei. Endocrinology. 1998 May;139(5):2600-4.

76 Oyola MG, Thompson MK, Handa AZ, Handa RJ. Distribution and chemical composition of estrogen receptor $\beta$ neurons in the paraventricular nucleus of the female and male mouse hypothalamus. J Comp Neurol. 2017 Dec;525(17):3666-82.

77 Handa RJ, Ogawa S, Wang JM, Herbison AE. Roles for oestrogen receptor $\beta$ in adult brain function. J Neuroendocrinol. 2012 Jan;24(1): 160-73.

78 Tsuda MC, Yamaguchi N, Nakata M, Ogawa S. Modification of female and male social behaviors in estrogen receptor beta knockout mice by neonatal maternal separation. Front Neurosci. 2014 Sep;8:274.

79 Biag J, Huang Y, Gou L, Hintiryan H, Askarinam A, Hahn JD, et al. Cyto- and chemoarchitecture of the hypothalamic paraventricular nucleus in the C57BL/6J male mouse: a study of immunostaining and multiple fluorescent tract tracing. J Comp Neurol. 2012 Jan;520(1):6-33.

80 Zhang R, Asai M, Mahoney CE, Joachim M, Shen Y, Gunner G, et al. Loss of hypothalamic corticotropin-releasing hormone markedly reduces anxiety behaviors in mice. Mol Psychiatry. 2017 May;22(5):733-44. 
81 Ludwig M, Leng G. Dendritic peptide release and peptide-dependent behaviours. Nat Rev Neurosci. 2006 Feb;7(2):126-36.

82 Liebsch G, Wotjak CT, Landgraf R, Engelmann M. Septal vasopressin modulates anxiety-related behaviour in rats. Neurosci Lett. 1996 Oct;217(2-3):101-4.

83 Everts HG, Koolhaas JM. Differential modulation of lateral septal vasopressin receptor blockade in spatial learning, social recognition, and anxiety-related behaviors in rats. Behav Brain Res. 1999 Feb;99(1):7-16.

84 Wigger A, Sánchez MM, Mathys KC, Ebner $\mathrm{K}$, Frank E, Liu D, et al. Alterations in central neuropeptide expression, release, and receptor binding in rats bred for high anxiety: critical role of vasopressin. Neuropsychopharmacology. 2004 Jan;29(1):1-14.

85 Murgatroyd C, Wigger A, Frank E, Singewald $\mathrm{N}$, Bunck M, Holsboer F, et al. Impaired repression at a vasopressin promoter polymorphism underlies overexpression of vasopressin in a rat model of trait anxiety. J Neurosci. 2004 Sep;24(35):7762-70.

86 Bunck M, Czibere L, Horvath C, Graf C, Frank E, Kessler MS, et al. A hypomorphic vasopressin allele prevents anxiety-related behavior. PLoS One. 2009;4(4):e5129.

87 Tanaka K, Osako Y, Yuri K. Juvenile social experience regulates central neuropeptides relevant to emotional and social behaviors. Neuroscience. 2010 Apr;166(4):1036-42.

88 Blume A, Bosch OJ, Miklos S, Torner L, Wales $\mathrm{L}$, Waldherr $\mathrm{M}$, et al. Oxytocin reduces anxiety via ERK1/2 activation: local effect within the rat hypothalamic paraventricular nucleus. Eur J Neurosci. 2008 Apr;27(8):1947-56.
89 Bluthé RM, Dantzer R. Social recognition does not involve vasopressinergic neurotransmission in female rats. Brain Res. 1990 Dec;535(2):301-4.

90 Markham JA, Juraska JM. Social recognition memory: influence of age, sex, and ovarian hormonal status. Physiol Behav. 2007 Dec; 92(5):881-8.

91 Holmes MM, Niel L, Anyan JJ, Griffith AT, Monks DA, Forger NG. Effects of Bax gene deletion on social behaviors and neural response to olfactory cues in mice. Eur J Neurosci. 2011 Nov;34(9):1492-9.

92 Karlsson SA, Haziri K, Hansson E, Kettunen P, Westberg L. Effects of sex and gonadectomy on social investigation and social recognition in mice. BMC Neurosci. 2015 Nov; 16(1): 83.

93 Veenema AH, Neumann ID. Central vasopressin and oxytocin release: regulation of complex social behaviours. Prog Brain Res. 2008; 170:261-76.

94 Veenema AH, Beiderbeck DI, Lukas M, Neumann ID. Distinct correlations of vasopressin release within the lateral septum and the bed nucleus of the stria terminalis with the display of intermale aggression. Horm Behav. 2010 Jul;58(2):273-81.

95 Leroy F, Park J, Asok A, Brann DH, Meira T, Boyle LM, et al. A circuit from hippocampal CA2 to lateral septum disinhibits social aggression. Nature. 2018 Dec;564(7735):213-8.
96 Ferris CF, Axelson JF, Martin AM, Roberge LF. Vasopressin immunoreactivity in the anterior hypothalamus is altered during the establishment of dominant/subordinate relationships between hamsters. Neuroscience. 1989;29(3):675-83.

97 Gobrogge KL, Liu Y, Jia X, Wang Z. Anterior hypothalamic neural activation and neurochemical associations with aggression in pair-bonded male prairie voles. J Comp Neurol. 2007 Jun;502(6):1109-22.

98 Cheng SY, Taravosh-Lahn K, Delville Y. Neural circuitry of play fighting in golden hamsters. Neuroscience. 2008 Oct;156(2): 247-56.

99 Smith CJ, Poehlmann ML, Li S, Ratnaseelan AM, Bredewold R, Veenema AH. Age and sex differences in oxytocin and vasopressin V1a receptor binding densities in the rat brain: focus on the social decision-making network. Brain Struct Funct. 2017 Mar; 222(2):981-1006.

100 Song Z, Albers HE. Cross-talk among oxytocin and arginine-vasopressin receptors: relevance for basic and clinical studies of the brain and periphery. Front Neuroendocrinol. 2018 Oct;51:14-24.

101 McCall JG, Al-Hasani R, Siuda ER, Hong DY, Norris AJ, Ford CP, et al. CRH Engagement of the Locus Coeruleus Noradrenergic System Mediates Stress-Induced Anxiety. Neuron. 2015 Aug;87(3):605-20.

102 Valentino RJ, Bangasser DA. Sex-biased cellular signaling: molecular basis for sex differences in neuropsychiatric diseases. Dialogues Clin Neurosci. 2016 Dec;18(4):38593.
PVN AVP and Social Communication and Behavior in Mice
Neuroendocrinology 2021;111:521-535

DOI: $10.1159 / 000509421$ 